Польща

b.halczak@wpa.uz.zgora.pl

\title{
ОПЕРАЦІЯ „ВІСЛА” У ПОЛЬЩІ В 1947 РОЦІ
}

Абстракт: 28 квітня 1947 року шість девізій Польської Армії розпочали операцію „Вісла”, яка тривала три місяці. У цей період з південно-східної частини польської держави переселили близько 150000 українців, а також членів змішаних сімей. Їх було примусово виселено на західні й північні території польської держави та розпорошено поміж етнічним польським населенням. Це один з найскладніших епізодів в історії польсько-українських відносин.

Ключові слова: операція „Вісла”, депортація, Польща, українська національна меншина.

До 1989 року у Польщі про операцію „Вісла” було написано мало і переважно з ідеологічних міркувань. Після краху системи комуністичного правління в Польщі наступив своєрідний вибух публікацій з цієї теми. Наукові роботи Романа Дрозда (Drozd, 1997, 2001), Свгенія Місило (Misiło, 1993), а також інших авторів висвітлили низку питань, пов'язаних 3 підготовкою, виконанням та наслідками операції „Вісла”. Тим не менш, так і не виявлено основної причини проблеми: 3 якою метою комуністична влада вирішила провести цю операцію? Щоправда, історика, який займається проблематикою новітньої історії Центральної та Східної Свропи, цей факт не дивує.

Виявити реальні наміри комуністичної влади часто буває проблематично чи навіть неможливо, незважаючи на доступ до документів, які були нею написані. Обгрунтовуючи свої рішення, співробітники партійного апарату, використовували такі аргументи, які були вигідні для них, не турбуючись про їх відповідність правді або їхнім же попереднім висловлюванням. Вдало прикриваючись пропагандистськими кліше, вони маніпулювали людьми й досягали мети. У країнах колишнього Радянського Союзу таку аргументацію називали ідейно-політичною або масово-роз'яснювальною.

Однак це не означає, що в документах для внутрішнього використання, комуністи були щирі. Назагал документація була зредагована специфічною 
діловою мовою, яку до 1989 р. в Польщі називали „партійною новомовою”. Здебільшого вона була схожа на збірку пропагандистських цитат, узятих 3 офіційних публікацій та виступів тогочасних державних керівників. „Новомовою" не тільки писали, але й говорили під час зібрань та, навіть, у вузьких колах керівників. Комуністичні діячі побоювалися один одного, оскільки в партії процвітали доноси. Необережно сказане слово могло зашкодити кар'єрі або призвести до виключення з лав партії.

Комуністична влада Польщі спочатку виправдовувала операцію „Вісла” необхідністю застосування репресивних дій щодо українців після організованого 28 березня 1947 року УПА замаху на заступника міністра національної оборони генерала Кароля Свєрчевского (Misiło, 1993: 65). 3 сучасної точки зору цей аргумент не переконливий. К. Свєрчевський не був таким значущим у комуністичному уряді, аби після його смерті необхідно було вдатися до таких різких заходів. Крім того, він не був беззахисною дитиною, яку жорстоко вбили. Генерал мав зброю, був професійним військовим у воєнній формі, який загинув у бою. I, нарешті, дослідження Романа Дрозда підтверджують, що підготовку до операції „Вісла” було розпочато ще до його смерті (Drozd, 2001: 62-63). Та, незважаючи на це, протягом багатьох років пропаганда репрезентувала операцію „Вісла” як справедливу кару за смерть народного героя і розповсюджувала саме такий варіант пояснення.

Наприкінці існування комуністичної диктатури в Польщі влада вже менше експонувала постать К. Свєрчевського. Дійшло навіть до модифікації попередньої теорії. Офіційною пропагандою було визнано негуманний характер акції, але одночасно стверджувалося, що вона була необхідною для знищення українського підпілля (Sikorski, 1989: 178; Bata, 1987: 207; Pudło, 1987: 28-29).

Цей аргумент також не варто сприймати серйозно. Річ у тім, що в 1947 p. в боротьбу проти українських партизанів було залучено майже 21 тисячу польських солдатів й офіцерів поліції, які були набагато краще озброєні, ніж повстанці (Misiło, 1993: 26; Motyka, 1999: 407). Під час проведення операції „Вісла” чехословацькі війська й НКВС блокували кордони. Кількість партизанів УПА тоді не перевищувала 2 тисячі (Misiło, 1993: 27; Motyka, 1999: 407). Тож, якби польська армія не змогла впоратися $з$ українським збройним підпіллям (інакше, ніж через виселення людей), то це могло б зганьбити військо.

Польська комуністична влада ніколи не давала правдивої відповіді на запитання про справжню мету операції „Вісла”. Відсутність достовірної інформації сприяла виникненню міфології навколо цього питання (Drozd, Halczak, 2010: 159-173). Кожний, хто торкався цієї теми, намагався виправдати ганебні дії влади. 
Так, частина польського суспільства схильна вбачати в операції „Вісла” справедливе покарання українського населення Польщі за напади підрозділів УПА на польське цивільне населення на Волині й у Галичині в 19431945 pp. Така думка містить у собі логічне протиріччя. Помста за події на Волині щодо людей, які не могли мати жодного зв'язку з ними (наприклад, щодо лемків з Нижніх Бескид), немає нічого спільного з правосуддям. Підвищення статусу комуністичних керівників Польщі до рівня „народних месників" дозволяє розглядати вищезазначене пояснення тільки в міфологічних категоріях. На жаль, ніщо не вказує на те, що влада переймалася долею своїх співвітчизників на Сході.

Серед сучасних польських істориків найбільшою популярністю користується теорія, згідно з якою комуністична влада Польщі здійснила операцію „Вісла” за наказом Радянського Союзу. Популяризатором цієї думки був відомий фахівець 3 польсько-українських відносин Ришард Тожецький. У своїй праці, що була опублікована у 1993 р., він стверджував, що це „рішення з йолітиччними насліgками мойли иррийняйи Сйалін або Берія” (Torzecki, 1993: 302). Не наводячі ніяких конкретних доказів на підтримку своєї гіпотези, він зазначив: „У зв’язку з віgсуйністию раяянських докумениіві, сиррава йовинна й gалі розіляяайися" (Torzecki, 1993: 302). У даному припущенні Р. Тожецького багато істориків вбачають переконливі докази того, що операція „Вісла” була проведена за наказом Йосипа Сталіна.

Між тим пізніше проведені дослідження не підтвердили його теорію. Навпаки, було вказано на те, що ініціатором була польська комуністична влада, яка намагалася отримати дозвіл на проведення операції „Вісла” від сильного радянського „союзника” та врешті-решт його отримала (Drozd, 2001: 61-63). Історики, які займаються історією країн Центральної та Східної Європи після Другої світової війни, дуже добре знають, що не можна довіряти документам повною мірою. Багато питань комуністична влада „вирішувала” без оформлення документації. Розпорядження надавалися в усній формі безпосередньо або по телефону. Припущення вчених про те, що СРСР був ініціатором проведення операції „Вісла”, має багато „недоліків”. Українці компактно проживали не тільки в Польщі, але й у Чехословаччині, Румунії та Угорщині. Але в цих країнах операція „Вісла” не мала такого відповідника.

Важко знайти раціональне пояснення й тому, яку користь мали керівники Радянського Союзу від депортації українського населення на так звані „Відзискані” землі Польщі. Звичайно була зацікавленість у ліквідації українського підпілля у цій країні, але було й розуміння того, що депортація не $\epsilon$ необхідною. Насправді, примусове переселення і розселення українського люду у західних і північних воєводствах Польщі було проблемним для радянської влади. Це була стратегічна територія, де знаходилося багато ра- 
дянських військових баз. Тож, якщо радянська влада вважала українське населення небезпечним, то чому направляла його на ці території? Більше того, депортованих українців часто поселяли в безпосередній близькості до цих військових баз. Чому такі дії польської влади не викликали жодної реакції зі сторони радянської влади?

Водночас, у світлі сучасних знань, не можна заперечувати спільної відповідальності урядів обох країн за операцію „Вісла”. Без згоди радянської сторони польська влада не наважилася б на такі радикальні заходи проти української етнічної меншини. Отже, теоретичне припущення про примус СРСР польського уряду до проведення операції „Вісла” можна розглядати лише в міфологічному аспекті.

Середовище української етнічної меншини в Польщі переконане в тому, що польські комуністи прийняли рішення про проведення операції „Вісла” виключно з націоналістичних мотивів. Таким чином, вони зреалізували концепцію, яка була сформульована ще в міжвоєнний період. Ця думка не позбавлена раціональної основи. Ідея „національної держави” з єдиним етнічним населенням, або яка гарантувала б польському етносу привілейовані позиції мала до війни велику підтримку в польському суспільстві (Halczak, 2000: 32-42).

Назагал II Річ Посполита була багатонаціональною державою, але в східних воєводствах переважало непольське населення. У зв'язку з цим, було розроблено проекти радикального національного „стандартизування” країни. У 1936 р. економіст Віктор Орміцький написав для Міністерства внутрішніх справ секретну доповідь щодо національної політики на східній території (Mironowicz, 2007: 230-232). В ній пропонувалося насильно переселити білоруську й українську людність на західні території, а польські родини у великій кількості переселити на схід таким чином, щоб у кожному окрузі Польської держави відсоток польського населення складав не менше, ніж 56,2 \%.

Тези цього проекту нагадують операцію „Вісла”. В обох випадках передбачалася примусова депортація українського населення на захід і поселення його таким чином, щоб не перевищувати зазначений відсоток етнічної меншини в новому місці проживання. Доповідь В. Орміцького спричинила в МВС дискусію на тему вибору концепції національної політики уряду. В період II Речі Посполитої цей проект не був реалізований.

Після Другої світової війни комуністична влада в Польщі проголосила ідею єдиної національної держави і досить плідно втілювали її в життя. У 1945 р. в нових кордонах польської держави проживало близько 4-х млн непольського етнічного населення (переважно німців) (Mironowicz, 2000: 32). Етнічних меншин налічувалося майже 17\% (Topolski, 1977: 845). У 1950 p. влада оцінювала кількість непольського населення близько 417 тис (Miro- 
nowicz, 2000: 94). Це не перевищувало 2\% населення. У 1945-1950 рр. кількість непольського населення в Польщі зменшилася до 3,6 млн осіб. Уніфікацію держави було отримано шляхом виселення переважної більшості непольського населення за кордон. Це стосувалося в основному етнічних німців та українців.

У 1944-1946 pр. переселено з Польщі на територію УРСР півмільйона людей (Drozd, 2001: 55). У 1947 р. керівники Радянського Союзу відмовилися приймати українців з Польщі, які не встигли переселитися до зазначеного терміну. Після невдалих спроб переконати радянську сторону продовжити строки переселення польський уряд вирішив провести депортаційну акцію українського населення на західні і північні території. Вона отримала назву „Вісла”.

Її ініціатором вважається заступник начальника Генерального Штабу Польської Армії генерал Стефан Мосор (Mironowicz, 2000: 61). 20 лютого 1947 р. у листі до міністра національної оборони Михайла Ролі-Жимерського він так окреслив мету акції: „У зв’язку з тим, що Радянський Союз не приймає вже цих людей, здається, є необхідним аби весною здійснити швидку акцію переселення і розпорошення цих людей окремими родинами на Відзисканих землях, де вони швидко асимілюються" (Misiło, 1993: 53). Окрім цього, в інструкції Міністерства відзисканих земель (МВ3, установа, яка займалася розселенням на західних і північних територіях польської держави, що після війни були забрані у Німеччини і передані Польщі), датованій листопадом 1947 р., щодо розподілу населення з операції „Вісла” зазначалося: „Основна мета переселення переселенців „В” є їх асиміляція в новому польському середовищі. Варто докласти всіх старань, щоб досягти мети" (Syrnyk, 2008: 19).

Наведені документи засвідчують націоналістичний спосіб мислення. Для націоналістів має велике значення уніфікована, з точки зору єдиної нації, держава (Gellner, 1991: 44). С. Мосор мав би розуміти, що його „проект” у випадку реалізації принесе страждання десяткам тисяч людей, а польська держава понесе величезні витрати. Вочевидь це вказує на те, що він був справжнім націоналістом. Інструкція ж МВ3 наказувала розсіювати українські родини на великій території. Безперечно, цей нелюдський вчинок був спрямований на те, щоб вирвати українців із звичного їм традиційного середовища, позбавити близькості родичів і друзів. Міністерство не переймалося тим, чи відповідають побутові умови на нових землях прийняттю депортованого населення, чи зможуть вони там господарювати та чи підходять німецькі будинки сім'ям з малими дітьми. Для чиновників важливою була тільки одна річ - асиміляція. Тому і працівники МВ3 також мали націоналістичні переконання. 
Звичайно, С. Мосор й апарат працівників МВ3 лише здійснювали функцію виконавчої влади. Вони не приймали рішення щодо реалізації операції „Вісла”. Вирішальний голос у справі української етнічної меншини в Польщі належав Політбюро ЦК Польської Робітничої Партії (ПРП). На його засіданні, що відбулося 29 березня 1947 р., було прийняло рішення про примусове переселення українського населення. Членами Політбюро були професійні комуністичні управлінці: Владислав Гомулка, Болеслав Берут, Роман Замбровський, Яків Берман, Хілари Мінц, Станіслав Радкевич, Маріуш Спихальський та Олександр Завадський. Це були люди з іншим менталітетом, ніж генерал С. Мосор (у міжвоєнний період був професійним офіцером Війська Польського) чи урядовці МВС, частина яких належала до польської правої націоналістичної партії.

Чим тоді керувалися зазначені члени Політбюро ЦК ПРП, коли приймали рішення про примусове переселення української людності? Їх націоналістична позиція $є$ дещо дивною. У 1944-1947 рр. посилювався сценарій васалізації польської держави Радянським Союзом. Комуністичні активісти Польщі не тільки не протестували, але навіть активно брали участь у процесі „узалежнення” своєї країни від східного сусіда. Маючи владу, вони переслідували діячів польської правої націоналістичної партії. Репресії були спрямовані навіть проти тих націоналістів, які вирішили співпрацювати 3 комуністами. У травні 1950 р. було заарештовано й засуджено до довічного ув'язнення генерала С. Мосора (звільнений у 1956 р., але невдовзі помер) (Misiło, 1993: 54). MВ3 було зліквідовано в 1949 р., а чимало його співробітників було репресовано.

Незважаючи на впровадження політики „уніфікації” польська комуністична влада неодноразово відступала від своєї „політичної лінії”. Прикладів не бракує. У 1945-1949 рр. польський уряд наполегливо виселяв з Речі Посполитої німецьке населення, застосовуючи і жорстокі методи. У 1950 р. ситуація несподівано змінилася. Німецьке населення не тільки не виселяли, але й перешкоджали йому виїжджати з Польщі, а згодом і повністю заборонили. Це було викликано головним чином економічними причинами (Słabig, 2008: 29-38). Слабка соціалістична економіка гостро потребувала кваліфікованої та продуктивної робочої сили в окремих регіонах. Її забезпечувала німецька етнічна меншина. Досить банальна економічна проблема, яку можна було б вирішити іншим шляхом, призвела до відмови комуністичної влади від націоналістичних принципів. Це призвело до утворення в деяких регіонах країни сильної німецької діаспори.

Польська комуністична влада теж не була послідовною і щодо українського населення. У 1956 р. вона дозволила створити Українське суспільнокультурне товариство (УСКТ). Йому надавалося право (в обмеженій мірі) здійснювати культурно-освітні заходи. Крім того, вона дозволила, хоча й 
неохоче, греко-католицькому духовенству вести пастирську роботу. Хоча церква офіційно і не була відновлена. Але окремі поступки українцям „не перекреслили" загальної політики влади щодо них. Українцям і надалі заборонялося повертатися на землі предків. Влада продовжувала реалізувати політику денаціоналізації українців, хоча і менш жорсткими методами. Процес полонізації української меншини значно загальмувався.

Чому в 1956 р. комуністична влада зважилася на пом'якшення націоналістичних принципів своєї політики щодо української меншини? Адже це не було ефектом тиску з боку закордонного покровителя, оскільки українці його не мали. Жодна фракція польської громадської думки, з якою рахувалися, не підтримувала українську меншину. Нарешті самі українці не мали реальних можливостей чинити тиск на владу.

Все це вказує на те, що керівництво польської держави вирішило піти на поступки, тому що так йому було вигідно. Завдяки УСКТ з'явилася можливість „направляти” діяльність українців у правові рамки і здійснювати більш ефективний контроль за внутрішнім життям цієї спільноти. Товариство працювало під пильним наглядом адміністрації, партії та спеціальних служб (Syrnyk, 2008: 171-325). Це забезпечило владі більш комфортні умови для керування всупереч націоналістичним принципам. Поступки 1956 р. сприяли стабілізації життя українців на „Відзисканих землях”. Партійна бюрократія вище цінила свою користь, ніж цінність ідеї.

У світлі представлених фактів важко стверджувати, що в 1947 р. комуністична влада в Польщі складалася виключно з фанатичних польських націоналістів. Позиція комуністів щодо націоналістичних ідей характеризувалася прагматизмом. Вони порівняно легко відступали від зазначених принципів, якщо це було, з їх точки зору, більш корисно. Чому все ж таки вона зважилися на проведення операції „Вісла”?

Щоб відповісти на це питання, необхідно поміркувати над тим, яку роль відігравали масові виселення і депортації в часи комуністичної диктатури. Влада використовувала ці методи досить часто. Першу велику акцію з виселення провели більшовики на Північному Кавказі під час громадянської війни в Росії. Спершу вони не мали великої підтримки в цьому регіоні. Тому використали конфлікт між російськими козаками, які заселяли кращі землі, та корінним населенням Кавказу - чеченцями й інгушами, які були скривджені царатом. У 1920 р. вони виселили з Кавказу близько 9 тис. родин (Ciesielski, 2003: 120-124). Їх землі передали чеченцям, які стали вірними союзниками більшовиків. Хоча це не завадило пізніше радянській владі жорстоко переслідувати чеченців. Для „вирішення” національних проблем більшовики неодноразово зверталися до методу, що був випробуваний на Північному Кавказі. Проте не тільки національні проблеми „вирішувалися” за допомогою виселення. 
Наприклад, у 1950 р. невелике містечко Зелена Гура (близько 31 тис. населення), що розташоване в західній частині Польщі, було піднесене до рангу обласного міста. У зв'язку з цим у місті спостерігався великий наплив працівників із різних установ, яких необхідно було забезпечити оселями. Переповнене місто не мало резервного житла, а державна влада не мала достатніх фінансових ресурсів не тільки на будівництво нових приміщень, але й на реконструкцію старих. Тоді місцева влада виселила частину жителів міста, а звільнені приміщення віддала у користування своїм співробітникам. Навіть у світлі сталінських законів це було незаконно. Та центральна влада у Варшаві, яка звісно була поінформована про діяльність зеленогурських „товаришів”, не скасувала протизаконні дії (Halczak, 2008: 147-158).

Виселення для комуністів було звичайним засобом вирішення проблем, навіть дуже простих. Це була своєрідна „філософія влади”. Основною метою існування держави було функціонування потужного партійно-бюрократичного апарату. Власність населення вважалася власністю держави, тимчасово переданою для використання у приватні руки. У такій державі окремі особи і соціальні групи могли існувати, якщо вони були потрібні „апарату” або мали впливового покровителя.

Отже, на мою думку, комуністична влада вирішила провести операцію „Вісла” тому, що бачила у цьому величезні переваги. Українське населення не мало покровителя і вона могла робити з ним все, що завгодно. На південно-східній території країни польські комуністи не мали сильного впливу. Це були сільськогосподарські консервативні регіони. Комуністичні ідеї не знаходили тут масової підтримки ані серед поляків, ані серед українців. Операція „Вісла” спричинила значне зростання підтримки „народної влади” серед місцевого польського населення і залагодила тліючий протягом багатьох років етнічний конфлікт. До покинутих українських сіл наплинуло населення з переповнених польських теренів. На них „очікували” по господарські улаштовані поля та луги, будинки та майно попередніх господарів.

Аналізуючи операцію „Вісла”, слід зауважити, що проводилася вона на користь польського етнічного населення. Терміни переселення кожного села були дивно збігалися із часом дозрівання зерна. Виселення відбувалося напередодні жнив, щоб депортоване населення не встигло зібрати врожай. Його здійснили швидко і без надання відповідної кількості транспортних засобів. Саме тому українське населення змушене було залишити значну кількість свого майна.

Депортовані на Західні та Північні землі українці збільшували відсоток слов'янського населення на колишніх німецьких територіях, із заселенням яких комуністична влада мала проблеми. Часто після захоплення великої частини залишеного німецьким населенням майна польські переселенці 
поверталися „до рідних сторін”. „Переселенці” з операції „Вісла” такої можливості не мали. Вони були змушені поселятися лише у відведених для них владою нових місцях та не мали права звідти виїжджати. Позбавлені засобів до існування депортовані українці поповнили ряди дешевої робочої сили. На думку польської комуністичної влади, вони були „ідеальним типом поселенця".

Операція „Вісла” мала не тільки нелюдський характер, але й була нісенітницею з економічної точки зору. Вона призвела до величезних державних витрат. Масове переселення людей потребувало транспортних засобів, харчування та залучення великої кількості працівників відповідних служб і чиновників. Необхідно було також надавати матеріальну допомогу депортованим. Українське населення, переселене на землі з іншими умовами господарювання, часто було не в змозі на ній господарювати. Тоді як землі, на яких до 1947 р. проживало українське населення, залишалися переважно незаселеними. Операція „Вісла” завдала польській державі таких величезних збитків і витрат, яких не змогло б завдати українське підпілля, навіть якщо б його діяльність тривала ще рік.

Та це не мало великого значення для комуністичної влади. Понад усе ставилися „апаратні” державні інтереси. Українське населення не було потрібне в південно-східній частині держави і навпаки - було потрібне на західних і північних землях. У такому випадку його необхідно було депортувати.

Це тільки наше припущення. Ймовірно, ми ніколи не дізнаємося причини здійснення польською комуністичною владою операції „Вісла”. Легше було депортувати десятки тисяч людей, ніж аргументовано обгрунтувати рішення. Цю велику безглуздість злочинної дії, на жаль, не в змозі зрозуміти деякі польські історики, які наполегливо намагаються її виправдати (Коnieczny, 2010: 298-306).

\section{ЛІТЕРАТУРА}

Bata A. (1987). Bieszczady w ogniu. Rzeszów: Krajowa Agencja Wydawnicza.

Ciesielski S. (2003). Rosja - Czeczenia. Dwa stulecia konfliktu. Wrocław: Wydawnictwo Uniwersytetu Wrocławskiego.

Drozd R. (2001). Polityka władz wobec ludności ukraińskiej w Polsce w latach 1944-1989. Warszawa: Wydawnictwo „Tyrsa”.

Drozd R. (1997). Droga na zachód. Osadnictwo ludności ukraińskiej na ziemiach zachodnich i północnych Polski w ramach akcji ,Wisła”. Warszawa: Wydawnictwo „Tyrsa”.

Drozd R., Halczak B. (2010). Dzieje Ukraińców w Polsce w latach 1921-1989. Warszawa: Wydawnictwo „Tyrsa”.

Gellner E. (1991), Narody i nacjonalizm. Warszawa: Państwowy Instytut Wydawniczy. 
Halczak B. (2008). Kwaterunek urzędników wojewódzkich w Zielonej Górze w roku 1950. Studia Zachodnie, nr 10. Zielona Góra: Oficyna Wydawnicza Uniwersytetu Zielonogórskiego.

Halczak B. (2000). Publicystyka narodowo-demokratyczna wobec problemów narodowościowych i etnicznych II Rzeczypospolitej. Zielona Góra: Wydawnictwo Wyższej Szkoły Pedagogicznej.

Konieczny Z. (2010). Polacy i Ukraińcy na ziemiach obecnej Polski w latach 1918-1947 (zarys problematyki). Przemyśl: Archiwum Państwowe w Przemyślu.

Misiło E. (1993). Akcja ,Wista”. Dokumenty. Warszawa: Archiwum Ukraińskie.

Sikorski F. (1989). Kabewiacy w akcji ,,Wista”. Warszawa: Wydawnictwo Ministerstwa Obrony Narodowej.

Pudło K. (1987). Łemkowie. Proces wrastania w środowisko Dolnego Ślaska 1947-1985. Wrocław: Polskie Towarzystwo Ludoznawcze.

Motyka G. (1999). Tak było w Bieszczadach. Walki polsko-ukraińskie 1943-1948. Warszawa: Oficyna Wydawnicza Volumen.

Mironowicz E. (2007). Białorusini i Ukraincy w polityce obozu piłsudczykowskiego. Białystok: Wydawnictwo Uniwersyteckie Trans Humana.

Mironowicz E. (2000). Polityka narodowościowa PRL. Białystok: Białoruskie Towarzystwo Historyczne.

Słabig A. (2008). Aparat bezpieczeństwa wobec mniejszości narodowych na Pomorzu Zachodnim w latach 1945-1989. Szczecin: Instytut Pamięci Narodowej.

Syrnyk J. (2008). Ukraińskie Towarzystwo Społeczno-Kulturalne (1956-1990). Wrocław: Instytut Pamięci Narodowej.

Topolski J. (1977). Dzieje Polski. Warszawa: Państwowe Wydawnictwo Naukowe.

Torzecki R. (1993). Polacy i Ukraincy. Sprawa ukraińska w czasie II wojny światowej na terenie II Rzeczypospolitej. Warszawa: Wydawnictwo Naukowe PWN.

Bohdan Halczak

\section{OPERATION "VISTULA” IN POLAND IN 1947}

\section{SUMMARY}

29 April 1947, six divisions of the Polish army launched operation „Vistula”. It lasted three months. During this period, from the south-eastern areas of the Polish state they were displaced almost 150,000 Ukrainians and members of mixed families. They were deported to western and northern areas of the Polish state and dispersed among the Polish population. This is one of the most difficult episodes in the history of Polish-Ukrainian relations.

Keywords: Operation "Vistula", deportation, Polish, Ukrainian national minority. 